\title{
Ticles (Amblyomma sp.) on an Indian Star Tortoise (Geochelone elegans) in the Gir Forest, Gujarat, India
}

\author{
Raju Vyas ${ }^{1}$ and Manoj Thaker ${ }^{2}$
}

${ }^{1} 1$-Shashwat Apartment, 23 Anandnagar Society, BPC Road, Alkapuri, Vadodara-390007, Gujarat, India (razoovyas@hotmail.com) 2352/C Divyajyot Society, Nr. Akashvani, Makarpura Road, Vadodara-390007, Gujarat, India

$\mathrm{T}$ The Indian Star Tortoise, Geochelone elegans (Testudinidae), is a medium-sized tortoise endemic to the Indian Subcontinent. Typical carapace length (CL) of females is $32 \mathrm{~cm}$ but individuals with $\mathrm{CL}>50 \mathrm{~cm}$ are known; male CL ranges to $26 \mathrm{~cm}$ (D'Cruze et al. 2018). The species occurs in scrub forests, grasslands, and some coastal scrublands of arid and semi-arid regions as well as in human-dominated landscapes, including agricultural fields, hedgerows, and plantations, in Pakistan, India, and Sri Lanka (D'Cruze et al. 2018). Three genetically distinct allopatric western, southern, and Sri Lankan populations exist (Gaur et al. 2005; D'cruze et al. 2018).
The largest portion of the western population occurs in Gujarat, where the largest expanse of protected habitat is in the Gir Forest (Das 1995; Vyas 2011, 2015; D’Cruze et al. 2018). The Gir Forest encompasses about $3,200 \mathrm{~km}^{2}$, including three protected areas (Gir National Park \& Sanctuary and the Pania Wildlife Sanctuary) that provide the last remaining refuge of the Asiatic Lion (Panthera leo persica).

On 17 September 2015, returning from a visit to the Gir Interpretation Zone, we encountered a large Indian Star Tortoise (Geochelone elegans) at the edge of the road (Fig. 1) about $3 \mathrm{~km}$ from Suraigadh $\left(21.20012^{\circ} \mathrm{N}, 70.52464^{\circ} \mathrm{E}\right)$. It was a female $(23 \mathrm{~cm} \mathrm{CL})$ over 18 years old (age estimated by

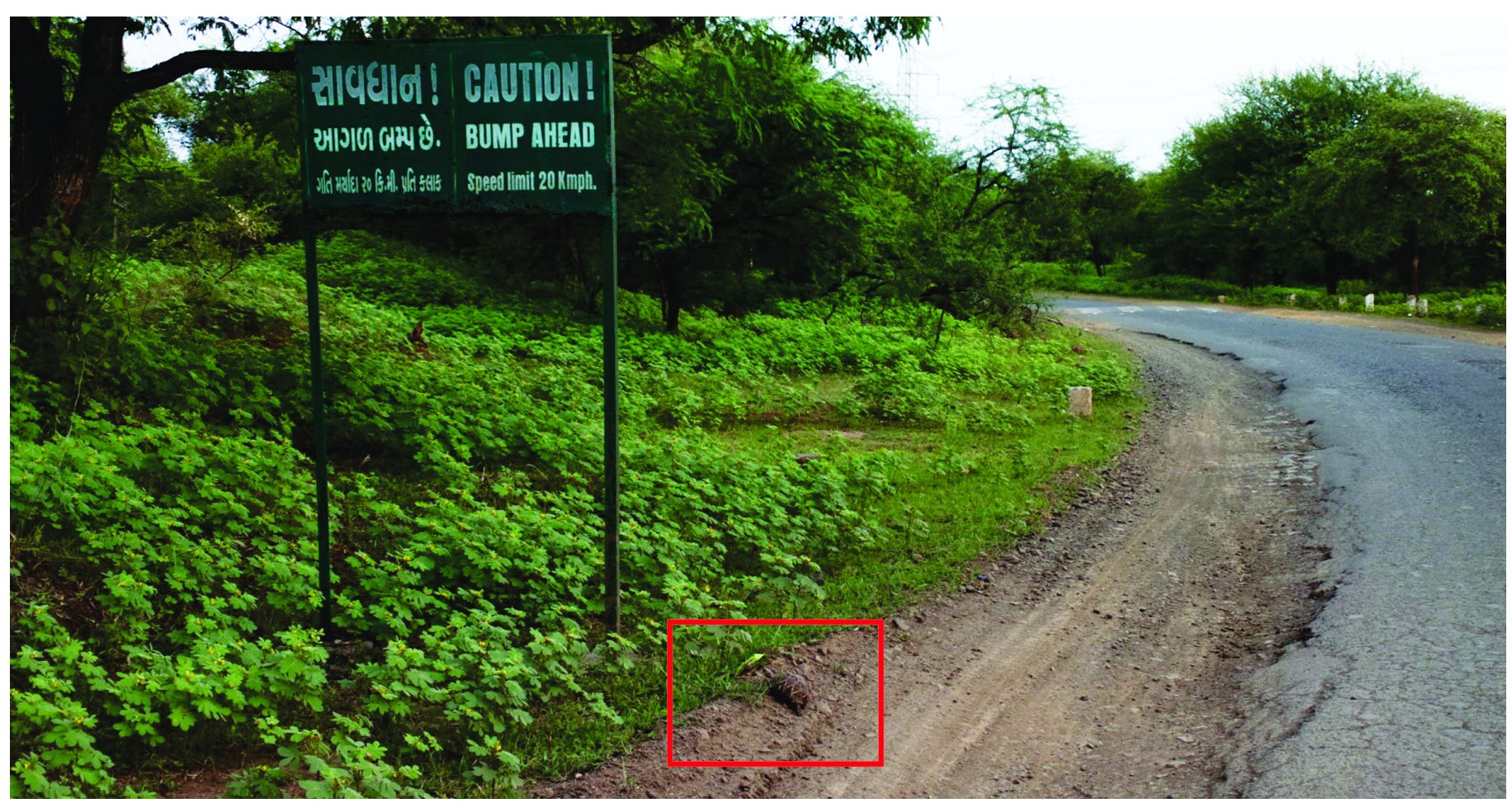

Fig. 1. A large female Indian Star Tortoise (Geochelone elegans) having just crossed a road in the Gir Forest, Gujarat, India. Photograph by Manoj Thaker. 


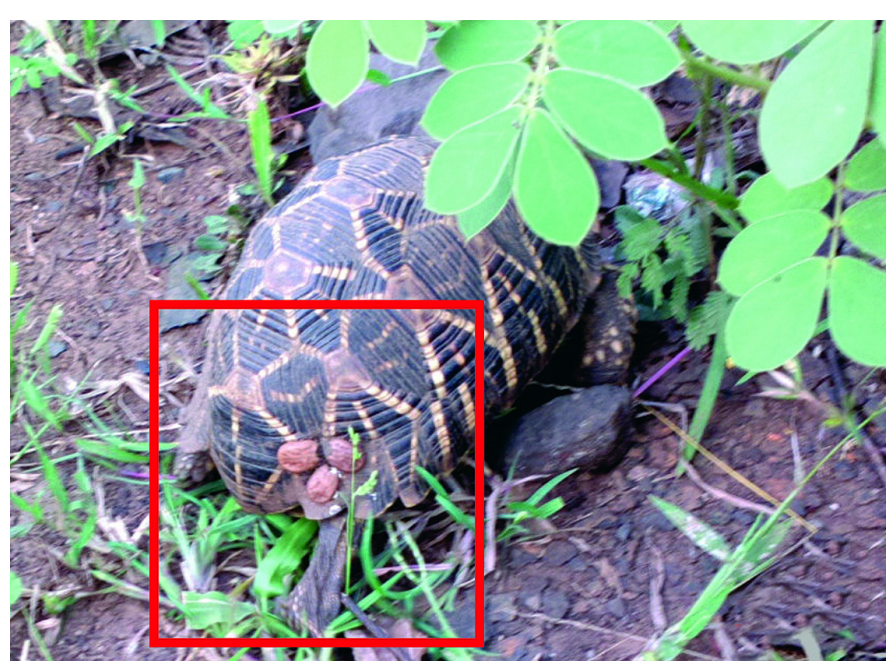

Fig. 2. A large female Indian Star Tortoise (Geochelone elegans) from the Gir Forest, Gujarat, India, infested with ticks (Amblyomma sp.). Photograph by Manoj Thaker.

counting carapacial growth rings). Three large female ticks were attached along a suture on the right side of the carapace (Fig. 2) and another small tick was on the base of the tail. We collected the ticks and, using criteria in Robinson (1926) and Miranpuri and Gill (1983), identified them as Amblyomma sp. (most likely A. clypeolatum).

Three species of ticks (Amblyomma clypeolatum, A. testudinarium, and Haemaphysalis turturis) have been reported parasitizing Indian Star Tortoises (Liyanaarachchi et al. 2015). In particular, A. clypeolatum is known to occur on various populations of Indian Star Tortoises in nature and in captivity (Nathanael et al. 2004). This tick has been recorded from India (including Gujarat) and Sri Lanka (Warburton 1925; Robinson 1926; Sharif 1928; Seneviratna 1965; Sharma 2001). Frazier and Keirans (1990) reported tick infestations on 5 of 9 Indian Star Tortoises in Andhra Pradesh (56\%, individuals) but only on 2 of 90 tortoises from Rajasthan and Gujarat. Srinivasulu and Srinivasulu (2002) found ticks on 2 of 19 tortoises. Such widely varying counts suggest that levels vary locally.

\section{Acknowledgements}

We thank the Deputy Conservator of Forest, Gir Sanctuary \& National Park for help and support. Special thanks also to the Wildlife Warden, Principal Wildlife Conservator of Forest, Gujarat Forest Department, Gandhinagar, Gujarat.

\section{Literature Cited}

Das, I. 1995. Turtles and Tortoises of India. Oxford University Press, Bombay, India.

D'Cruze, N., A. Mookerjee, R. Vyas, D.W. Macdonald, and A. de Silva. 2018. Geochelone elegans (Schoepff 1795) - Indian Star Tortoise, Star Tortoise. In: A.G.J. Rhodin, J.B. Iverson, P.P. van Dijk, C.B. Stanford, E.V. Goode, K.A. Buhlmann, P.C.H. Pritchard, and R.A. Mittermeier (eds.), Conservation biology of freshwater turtles and tortoises: A compilation project of the IUCN/SSC Tortoise and Freshwater Turtle Specialist Group. Chelonian Research Monographs 5: 106.1-106.13.

Frazier, J.G. and J.E. Keirans. 1990. Ticks (Acari: Ixodidae) collected on chelonians (Reptilia) from India and Burma. Journal of the Bombay Natural History Society 87: 247-249.

Gaur, A., A. Reddy, S. Annapurna, B. Satyarebala, and S. Shivaji. 2006. The origin of Indian Star Tortoises (Geochelone elegans) based on nuclear and mitochondrial DNA analysis: A story of rescue and repatriation. Conservation Genetics 7: $231-240$.

Liyanaarachchi, D.R., R.S. Rajakaruna, A.W. Dikkumbura, A. de Silva, and R.P.V.J. Rajapakse. 2015. Ticks (Acarina: Ixodida) infesting five reptile species in Sri Lanka with sixteen new host records. Zootaxa 3964: 146-148.

Miranpuri, G.S. and H.S. Gill. 1983. Ticks of India. Lindsay \& Macleod, Edinburgh, Scotland.

Nathanael, S., S.M.M. Samarakoon, N.D. Warusamanna, R.P.V.J. Rajapakse, and A. de Silva. 2004. Preliminary observations on parasites of captive Star Tortoises (Geochelone elegans) in Sri Lanka. Testudo 6: 46-51.

Robinson, L.E. 1926. The Genus Amblyomma. Part IV (The First Part of Volume II). In: G.H.F. Nuttall, C. Warburton, and L.E. Robinson, Ticks. A Monograph of the Ixodoidea. Cambridge University Press, London, UK.

Seneviratna, P. 1965. The Ixodoidea (Ticks) of Ceylon. Parts II \& III. Ceylon Veterinary Journal 13: 28-54.

Sharif, M. 1928. A revision of the Indian Ixodidae with species reference to the collection in the Indian Museum. Records of the Indian Museum 30: 217-344.

Sharma, S.K. 2001. A note on the ectoparasitic ticks of reptiles from southern Rajasthan. Journal of the Bombay Natural History Society 98: 455-456.

Srinivasulu, C. and B. Srinivasulu. 2002. A note on Ambylomma clypeolatum Neumann, 1899 (Acari: Ixodidae) on the Star Tortoise Geochelone elegans (Schoepff, 1792). Hamadryad 27: 154-155.

Vyas, R. 2011. The status of north-western population of Star Tortoise (Geochelone elegans), pp. 97-104. In: K. Vasudevan (ed.), Freshwater Turtles and Tortoises of India. ENVIS Bulletin. Wildlife and Protected Areas Volume 12. Wildlife Institute of India, Dehradun, India.

Vyas, R. 2015. Jeopardized future of Indian Star Tortoise Geochelone elegans. Reptile Rap 17: 13-18.

Warburton, C. 1925. Report on Ixodidae of the Colombo Museum. Spolia Zeylanica 13: 255-256. 